SERGIEJ POLECHOW (Instytut Nauk Społecznych Rosyjskiej Akademii Gospodarki Narodowej i Administracji Publicznej, Moskwa) https://orcid.org/0000-0001-7866-7663

SOBIESŁAW SZYBKOWSKI (Uniwersytet Gdański, Gdańsk) https://orcid.org/0000-0001-9366-8568

\title{
Nowe źródło do dziejów kształtowania się polskiej reprezentacji stanowej w późnym średniowieczu Raport krzyżackiego informatora Mikołaja Steinchena z początku grudnia 1432 roku
}

Zarys treści: W przyczynku dokonuje się krytycznej analizy raportu krzyżackiego informatora działającego na pograniczu ziemi dobrzyńskiej, Mazowsza i Prus, Mikołaja Steinchena, a także edycji tego źródła, które powstało na początku grudnia 1432 r. Raport ten jest również nieznanym dotąd źródłem do dziejów kształtowania się polskiej reprezentacji stanowej.

Abstract: The paper presents a critical analysis of the report of Nikolaus Steinchen, the informer of the Teutonic Knights, active on the borderland area of Dobrzyń Land, Masovia and Prussia, as well as the edition of that source, which was written at the beginning of December 1432. The report also contains (so far unknown) information for the history of Polish estate representation development.

Słowa kluczowe: wywiad, szpiedzy, Królestwo Polskie, krzyżackie Prusy, Władysław Jagiełł, reprezentacja stanowa, zjazdy generalne, rody rycerskie

Keywords: intelligence, spies, Kingdom of Poland, Prussia of Teutonic Knights, Ladislaus Jagiello, estate representation, general meetings, chivalric clans

1. O niezwykle wysokiej wartości informacyjnej zbioru korespondencji z archiwum pokrzyżackiego, przechowywanego obecnie w Geheimes Staatsarchiv Preussischer Kulturbesitz w Berlinie-Dahlem, nie trzeba już przekonywać środkowoeuropejskich, a w szczególności polskich mediewistów ${ }^{1}$. Listy z tego zespołu odzwierciedlają w wielkim stopniu wewnętrzną i zagraniczną politykę państwa Zakonu Krzyżackiego,

${ }^{1}$ Geheimes Staatsarchiv Preussischer Kulturbesitz (dalej cyt.: GSPK), XX. Hauptabteilung, Ordensbriefarchiv (dalej: OBA), Ordensfolianten; OBA i część zasobu Ordensfolianten zostały zregestowane w: Regesta historico-diplomatica Ordinis Sanctae Mariae Theutonicorum, t. I-III, opr. E. Joachim, wyd. W. Hubatsch, Göttingen 1948-1973 (dalej cyt.: RHD), systematyczna publikacja pełnych regestów z najstarszych OF odbywa się w ramach prac zespołu kierowanego przez Jürgena Sarnowsky'ego, zob. np. Regesten zu den Briefregistern des Deutschen Ordens: die Ordensfolianten 2a, 2aa und Zusatzmaterial, wyd. S. Kubon, J. Sarnowsky, Göttingen 2012. 
są jednak także niezastąpionym źródłem wiedzy o dziejach społecznych i gospodarczych tego obszaru. Sporo wnoszą również do dziejów późnośredniowiecznej Polski i to nie tylko w aspekcie relacji z północnym sąsiadem.

Poczesne miejsce wśród pokrzyżackich źródeł dotyczących relacji polsko-pruskich zajmują raporty informatorów i szpiegów Zakonu, pieczołowicie wykorzystane ostatnio przez Sławomira Jóźwiaka ${ }^{2}$. W źródłach tego rodzaju obok informacji o kwestiach natury politycznej, dyplomatycznej, wojskowej i ekonomicznej, czyli tego co najbardziej interesowało mocodawców wywiadu, znaleźć można, podawane niejako mimochodem, nieznane dotąd informacje ważne dla dziejów wewnętrznych późnośredniowiecznej Korony. Przypomnijmy omówione już przez S. Jóźwiaka przykłady nieznanego z imienia plebana z Murzynna, wysłanego w 1421 r. przez komtura nieszawskiego na zjazd do Inowrocławia, gdzie szlachta Kujaw i ziemi dobrzyńskiej debatowała nad proponowanymi przez króla kierunkami polityki krzyżackiej, a później zdającego o tym raport, albo relacje jednego z wybitniejszych krzyżackich szpiegów z okresu tuż przed wybuchem wojny trzynastoletniej, Mikołaja Scharara, raportującego szczegółowo komturowi toruńskiemu o przebiegu zjazdów generalnych w Polsce ${ }^{3}$.

2. Co najmniej podobną wagę ma inny raport, którym zajmiemy się w niniejszym artykule. Pochodzi od anonimowego informatora, a skierowany jest do nieznanego urzędnika krzyżackiego. Pismo nie jest wprawdzie datowane, ale niemieccy archiwiści kładli je na $1432 \mathrm{r}^{4}$ Zawarte w nim informacje pozwalają wszakże zarówno na ustalenie personaliów zakonnego szpiega, ,prowadzącego go" urzędnika krzyżackiego, jak i bliższej niż tylko roczna datacji tego przekazu.

Zakres kontaktów i powiązań informatora wyraźnie wskazuje, że swobodnie poruszał się on po ziemi dobrzyńskiej, a także po sąsiadujących z nią obszarach Mazowsza, gdzie zbierał interesujące jego mocodawców dane. Swoim panem nazywał biskupa płockiego, od którego otrzymał jakiś urząd lub funkcję. Jego bliskim współpracownikiem w szpiegowskiej „robocie” był zaś Bartold, należący do otoczenia podkanclerzego Królestwa. Wziąwszy pod uwagę to wszystko, autora raportu należy bez większych wątpliwości zidentyfikować ze „zdekonspirowanym” już przez S. Jóźwiaka Mikołajem Steinchenem, pozostającym na służbie biskupa płockiego Stanisława Pawłowskiego. W latach 1435-1436 posłował on w imieniu biskupa do Krzyżaków5. Znamy dwie inne relacje słane do Malborka w latach

${ }^{2}$ S. Jóźw i a k, Wywiad i kontrwywiad w państwie zakonu krzyżackiego w Prusach. Studium nad sposobami pozyskiwania i wykorzystywaniem poufnych informacji w późnym średniowieczu, Malbork 2004; t e n ż e, Na tropie średniowiecznych szpiegów. Wywiad i kontrwywiad w polsko-litewsko-krzyżackich stosunkach politycznych w XIV i pierwszej połowie XV wieku, Inowrocław 2005; zob. też J. G r a b o w s k i, Potęga służb specjalnych. Rola wywiadu i kontrwywiadu państwa zakonnego w Prusach, Zapiski Historyczne 72, 2007, s. $185-194$.

3 S. J ó źw i a k, Wywiad, s. 72, 73, 154, 155; te n ż e, Na tropie, s. 47-52.

${ }^{4}$ RHD I/1, nr 6304; pełen tekst publikujemy w aneksie.

5 GSPK, OBA, nr 7019; 7037; S. J ó ź w i a k, Na tropie, s. 65, 66; Steinchen był wówczas zarządcą (wójtem) należącej do biskupstwa płockiego wsi Orzechowo (zob. Słownik historyczno-geograficzny ziemi chełmińskiej w średniowieczu, opr. K. Porębska, M. Grzegorz, Wrocław 1971, s. 90) w komturstwie kowalewskim. 
1433 i 1435 za pośrednictwem komtura brodnickiego Jana von Gor. Obie pisane są tą samą ręką, która spisała interesujący nas raport pochodzący zapewne z 1432 r. ${ }^{6}$ To argument rozstrzygający o identyfikacji. Domyślać się przy tym można, że także analizowane tu pismo adresowane było do komtura brodnickiego. Dodajmy jeszcze, że Mikołaj Steinchen miał dowodnie brata (i, jak się okazuje, wspólnika w wywiadowczym rzemiośle) Bartolda, o czym dowiadujemy się z listu polecającego obu braci wielkiemu mistrzowi Pawłowi von Rusdorfowi, wystawionego w 1424 r. przez związanego majątkowo z ziemią dobrzyńską wojewodę inowrocławskiego Janusza ze Skępego i Kościelca7. Jeden z braci Steinchenów już w 1422 r. był przez Krzyżaków uważany za godnego zaufania informatora ${ }^{8}$. Według pochodzącego zapewne z pierwszej połowy lat trzydziestych XV w. listu komtura brodnickiego do wielkiego mistrza, Steinchen zamierzał nawet przenieść się do Prus ${ }^{9}$, nie wiadomo wszakże, czy zamiar ten zrealizował.

Mamy więc nadawcę i adresata raportu. Datowanie umożliwiają zwarte w nim dane. Mowa jest tam m.in. o tym, że wojewoda brzeski Jan z Lichenia w miniony poniedziałek w Bobrownikach wezwał szlachtę dobrzyńską do wysłania przedstawicieli na zjazd do Krakowa na Boże Narodzenie. Czas działalności Licheńskiego jako wojewody brzeskiego (był nim od 1430 r.) ${ }^{10}$ oraz lata aktywności szpiegowskiej Mikołaja Steinchena każą przyjąć, że chodzi o zjazd z udziałem króla Władysława Jagiełły rozpoczęty w Boże Narodzenie 1432 r. i trwający chyba aż do końca pobytu monarchy w stolicy, którą opuścił on po 13 I 1433 r. (16 stycznia był już w Niepołomicach) ${ }^{11}$. Wydaje się zatem, że raport został przez Mikołaja spisany jakiś czas przed tymi wydarzeniami - zapewne w pierwszej połowie grudnia, skoro szpieg pisał o wysłaniu do Krakowa swojego brata, który musiał wyjechać stosownie wcześniej, aby na zjazd zdążyć. Wniosek ten potwierdza itinerarium Jana z Lichenia. Jesienią wysłany został w poselstwie do wielkiego księcia litewskiego Zygmunta Kiejstutowicza do Grodna - 24 IX 1432 król wystawił w Lublinie mandat zawieszający sprawy sądowe Jana ${ }^{12}$, wciągnięty do ksiąg konińskich

${ }^{6}$ GSPK, OBA, nr 6347, 7117; zob. S. J óźw i a k, Wywiad, s. 161, 162; t e n że, Na tropie, s. 65, 66; ostatni z tych listów został już dwukrotnie opublikowany: Codex diplomaticus Lithuaniae, wyd. E. Raczyński, Wrocław 1845, s. 374-376; Codex epistolaris saeculi decimi quinti, t. I, wyd. A. Sokołowski, J. Szujski, Kraków 1876, t. II-III, wyd. A. Lewicki, Kraków 1891-1894 (dalej cyt.: CEp.), tu t. III, dodatek nr 25 (tu datowany na ok. 1 V 1435).

7 GSPK, OBA, nr 4271; regest: RHD I/1, nr 4271.

8 GSPK, OBA, nr 3912; regest: RHD I/1, nr 3912.

9 GSPK, OBA, nr 7875; regest: RHD I/1, nr 7875. Na taką orientacyjną datację listu wskazuje wzmianka o toczących się działaniach zbrojnych. Warto też zauważyć, że znane listy komtura brodnickiego do 1433 r. pisane są inną ręką. Wydawcy krzyżackich regestów datowali ten list, pozbawiony daty rocznej, ogólnie na lata rządów wielkiego mistrza Pawła von Rusdorfa (1422-1441).

${ }_{10}$ Zob. niżej, w edycji, przyp. 4.

11 Joannis Dlugossii Annales seu Cronicae incliti Regni Poloniae, lib. XI-XII, Varsaviae 2001, s. 79; A. G ą s i o r o w s k i, Itinerarium króla Władysława Jagiełły 1386-1434, wyd. 2, Warszawa 2015, s. 122.

${ }^{12}$ Kodeks dyplomatyczny Wielkopolski, t. IX, wyd. A. Gąsiorowski, T. Jasiński, Warszawa-Poznań 1989, nr 1297; С.В. П о л е х о в, Наследники Витовта. Династическая война в Великом княжестве Литовском в 30-е годы XV века, Москва 2015, s. 293. 
20 X 1432 r. ${ }^{13}$ Po przeprowadzeniu rozmów na Litwie, które zaowocowały m.in. odnowieniem unii, Licheński wrócił do Polski i 30 X 1432 r. wystąpił już u boku króla we Lwowie ${ }^{14}$. W rodzinne strony dotarł jednak znacznie później. Jeszcze 16 i 17 XI 1432 r. sąd koniński, powołując się na wspomnianą inhibicję królewską, przekładał bowiem ponownie jego sprawy jako pozostającego in mandato regali ${ }^{15}$. Jan mógł więc pojawić się na Kujawach najwcześniej pod koniec listopada, najpierw zwołał najpewniej (jako wojewoda brzeski) zjazd szlachty Kujaw Brzeskich, a dopiero potem udał się do ziemi dobrzyńskiej. Przypuszczamy zatem, że zjazd w Bobrownikach odbył się prawdopodobnie w poniedziałek 1 grudnia, co dałoby przedstawicielom szlachty dobrzyńskiej odpowiedni czas na przygotowanie się do drogi i dojazd do Krakowa na 25 grudnia. Interesujący nas tu raport Steinchena mógł zatem zostać spisany wkrótce po 1 XII $1432 \mathrm{r}^{16}$

Ponieważ autor pisma uważał za swego pana biskupa płockiego, a jednocześnie bardzo dobrze czytelne są jego związki z ziemią dobrzyńską (o czym przekonuje zakres informacji $w$ raporcie oraz dobre relacje $z$ dobrzyńskim starostą $\mathrm{i}$ terrigeną Januszem ze Skępego i Kościelca lub kimś z jego najbliższego otoczenia) wolno przypuszczać, że raport został spisany w jednej z wsi należącego do Kościoła płockiego klucza górzeńskiego ${ }^{17}$, ewentualnie w Łaszewie (już na terenie krzyżackiej ziemi michałowskiej $)^{18}$. O swoich związkach z tą biskupią wsią informuje bowiem sam Mikołaj Steinchen w raporcie z 1433 r. ${ }^{19}$

3. W tym miejscu wypada streścić raport krzyżackiego szpiega. Na jego wstępie donosi on swemu adresatowi, że w Polsce nie ma jednomyślności w zakresie dalszego prowadzenia wojny z Zakonem Krzyżackim: jedni opowiadają się za

${ }_{13}$ Poznań, Archiwum Państwowe, Konin Z. 3, k. 211v.

${ }^{14}$ CEp. I, nr 82; Б. Бу ч и н с ь к и й, Кілька причинків до часів вел. князя Свитригайла (1430-1433), Записки Наукового товариства ім. Шевченка 76, 1907, s. 137-139; Z. W i 1 k - W o ś, Władysław z Oporowa (ok. 1395-1453). Podkanclerzy królewski, biskup włocławski i arcybiskup gnieźnieński, Studia Claramontana 21, 2003, s. 269.

${ }_{15}$ Poznań, Archiwum Państwowe, Konin Z. 3, k. 220v, 225v.

${ }_{16}$ Chronologia taka odpowiada zawartym w raporcie informacjom o wydarzeniach wojennych na Wołyniu i w Czechach, zob. Urkundliche Beiträge zur Geschichte des Hussitenkrieges in den Jahren 1419-1436, t. II, wyd. F. Palacký, Prag 1873, nr 831; F. S tö 11 e r, Österreich im Kriege gegen die Hussiten, Jahrbuch für Landeskunde von Niederösterreich 22, 1929 , s. 76-77; С.В. П о л е х о в, Наследники, s. 294, 315-317.

17 Z. G u 1 d o n, J. P o w i e r s ki, Podziały administracyjne Kujaw i ziemi dobrzyńskiej w XIII-XIV wieku, Warszawa-Poznań 1974, s. 150, 151, 237. Raczej należy wykluczyć samo Górzno w ziemi dobrzyńskiej, ponieważ Steinchen w swoim raporcie pisze o przebywaniu w Górznie w czasie przeszłym (geleget).

18 Słownik historyczno-geograficzny ziemi chełmińskiej, s. 73; Z. G u l d o n, J. P o w i e r s k i, Podziały, s. 150.

19 S. J ó ź w i a k, Wywiad, s. 162; t e n że, Na tropie, s. 65. Mikołaj prosił, aby komtur brodnicki przysłał do niego, do Łaszewa, rycerza chełmińskiego Jana Langego z Bursztynowa z 15 grzywnami. Być może był więc zarządcą części klucza górzeńskiego znajdującej się po krzyżackiej stronie granicy (obok Łaszewa były to wsie Jastrzębie, Gołkówko i Grążawy), wiadomo wszak, że biskup powierzył mu jakiś urząd (von mym hern bisschoffe von Plotzke daz ampt entpfangen, zob. tekst źródłowy). 
pokojem, a inni za kontynuacją konfliktu. Niekorzystną okolicznością dla prowadzenia dalszych działań przeciwko Krzyżakom, zdaniem informatora, miało być to, że husyci, na których Polacy bardzo liczyli, nie mogą im przyjść z pomocą ze względu na sytuację wojenną w Czechach i na Morawach, gdzie walkę przeciw nim podjęło liczne wojsko zebrane przez królową węgierską Barbarę Cylejską. Wielu zbrojnych przeciwko nim poprowadził także książę austriacki Albrecht II Habsburg. W dalszej części Mikołaj Steinchen odniósł się do dyplomatycznych i propagandowych działań króla Władysława Jagiełły przeciwko Zakonowi w sąsiednich krajach, podsumowując, że jego posłom nikt nie daje wiary. Król miał wysłać także liczne oddziały zbrojne w celu zdobycia Łucka, ale nie zakończyło się to jeszcze sukcesem w postaci zajęcia tego ośrodka. Raport wspomina także, co wykorzystaliśmy wcześniej przy rozważaniach na temat datacji przekazu, o przybyciu do Bobrownik wojewody brzeskiego Jana z Lichenia, który wezwał szlachtę dobrzyńską na zjazd do Krakowa na 25 grudnia. Zgodnie z rozkazem królewskim szlachta wszystkich ziem polskich miała wydelegować tam po dwóch „starszych” z każdego herbu. Na zjeździe spodziewano się także „doradców” (czyli wysłanników) z okolicznych krajów: Węgier, Litwy, Brandenburgii i Czech. Podczas tego spotkania, według Steinchena, dojdzie do postanowień dotyczących kierunków polityki polskiej wobec Krzyżaków. Wydarzenie to miał obserwować osobiście jego brat Bartold, który znajdował się w otoczeniu podkanclerzego Królestwa Polskiego Władysława Oporowskiego, dzięki czemu adresat otrzyma interesujące go informacje z Krakowa już w dwa tygodnie po Bożym Narodzeniu. Mikołaj wyraził jednak przekonanie, że strona polska będzie przestrzegać rozejmu czartoryskiego z 2 IX 1431 r. Z relacji informatora wynika także, że poddani książąt mazowieckich byli niechętnie ustosunkowani do dalszej wojny z Krzyżakami i prosili swoich władców o zawarcie separatystycznego pokoju, nawet jeśli byłoby to wbrew woli króla. Doradzał to także biskup płocki Stanisław Pawłowski, który, jako osoba życzliwa pruskim mocodawcom szpiega, zamierzał nawet podjąć się pośrednictwa w tej sprawie. Komtur brodnicki uzyskał również od Mikołaja informację, że starosta dobrzyński, którego ojciec zmarł, wyjechał do króla. Wieści, które uzyska od niego po powrocie, również obiecywał przekazać do Brodnicy. Obecnie donosił, że na listowne polecenie króla starosta miał zachować pokój z Zakonem, zgodnie z postanowieniami rozejmu, nawet jeśli Krzyżacy podjęliby działania agresywne. Raport kończy się zapewnieniem adresata o gotowości służenia Zakonowi w postaci stałego przesyłania informacji, w związku z czym przebywał ostatnio osobiście w Górznie, gdzie, jak się pochwalił, uzyskał „urząd” od biskupa płockiemu, któremu służył. Podał także informacje: o śmierci Dobiesława Puchały (nieprawdziwą) oraz chorobie (zakończonej wszakże ozdrowieniem) Władysława Jagiełły, który zmierza właśnie z Lwowa do Krakowa ${ }^{20}$.

Waga i liczba informacji przekazanych przez autora raportu wydaje się bardzo znacząca, zarówno dla jego odbiorców, jak i współczesnej historiografii. W niniejszym tekście nie będziemy jednak szeroko komentować wszystkich z nich. Skupimy się jedynie na wybranych sprawach: wezwaniu przez króla reprezentacji szlacheckiej na zjazd krakowski, tożsamości starosty dobrzyńskiego występującego w źródle oraz

\footnotetext{
${ }^{20}$ Zob. tekst źródłowy, gdzie znajdują się objaśnienia dotyczące występujących w nim osób.
} 
datowaniu zajęcia wołyńskiego Łucka przez wojska królewskie, do czego raport Mikołaja wnosi nowe elementy chronologiczne.

Spośród spraw wewnętrznych Królestwa Polskiego poruszanych w reporcie Mikołaja Steinchena za najistotniejszą należy uznać ogłoszenie przez Jana z Lichenia na zjeździe ze szlachtą dobrzyńską w Bobrownikach królewskiego polecenia, aby na generalny zjazd w Krakowie, którego rozpoczęcie planowano na 25 XII 1432 r. z każdej ziemi Królestwa przybyło von itczlichem schilde uss itzlichem gebythe tzwene dy eldesten. Warto zatrzymać się nad znaczeniem niemieckich terminów schild i eldesten. Choć najlepiej pasującym thumaczeniem pierwszego z tych terminów jest „herb”, to w ówczesnej rzeczywistości społecznej Królestwa Polskiego i w danym kontekście rozumieć tu trzeba ród rycerski/szlachecki (clenodium). Potwierdzają to dokumenty hołdownicze szlachty Kujaw Brzeskich (1433) i ziemi dobrzyńskiej (1434), których wystawienie, jak pokażemy w dalszej części niniejszego tekstu, było konsekwencją zjazdu krakowskiego. Ich sygnatariuszami w grupie szlachty niesprawującej urzędów było po „dwóch z każdego rodu” (duo de quolibet clenodio $)^{21}$. Podobne ujęcie mamy w znanym tylko z formularza tekście dotyczącym zjazdu prowincjonalnego szlachty małopolskiej z 1423 r., gdzie stawić się mieli domini et duo de qualibet domo seu clenodio ${ }^{22}$. Z kolei pojęcie eldesten (,starsi”) z raportu Steinchena wydaje się być odpowiednikiem łacińskiego terminu seniores clenodiales, oznaczającego najznaczniejszych przedstawicieli konkretnych rodów rycerskich. Społeczne funkcje owych „starszych” szeroko omówił już Janusz Bieniak $^{23}$. Praktyka wspomnianych dokumentów brzeskiego i dobrzyńskiego oraz przeciwstawienie urzędników ziemskich (domini) reszcie reprezentacji szlacheckiej (duo de qualibet domo seu clenodio) ze źródła z 1423 r., każą seniores ograniczyć do najznaczniejszych przedstawicieli rodów rycerskich, niesprawujących wszakże urzędów ziemskich ${ }^{24}$. „Starsi z każdego herbu”, którzy mieli udać się na zjazd krakowski, byli zatem reprezentantami grupy, którą w dalszej części niniejszego artykuły będziemy określać umownie jako szlachtę nieurzędniczą.

Informacja ta, dotycząca kształtowania się polskiej reprezentacji stanowej i polskiego sejmu, nie była dotąd znana badaczom tych zagadnień. Wyraźnie wskazuje ona na podjęcie przez monarchę i jego otoczenie (skoro był to rozkaz królewski) próby sformalizowania reprezentacji stanowej wspomnianej wyżej grupy stanu szlacheckiego. W literaturze przedmiotu funkcjonowanie posłów ziemskich (nuncii terrarum) zauważano bowiem dopiero od zjazdu krakowskiego z października 1435 r., a więc już w okresie rządów opiekuńczych podczas małoletniości Władysława III,

${ }^{21}$ Kodeks dyplomatyczny Polski, t. II, cz. 2, wyd. A. Muczkowski, L. Rzyszczewski, Warszawa 1852, nr 576, 578.

${ }^{22}$ Liber cancellariae Stanislai Ciołek. Ein Formelbuch der polnischen Königskanzlei aus der Zeit der husitischen Bewegung, wyd. J. Caro, t. I-II, Wien 1871-1874, tu t. I, nr 8.

${ }^{23} \mathrm{~J}$. B i e n i a k, Rody rycerskie jako czynnik struktury społecznej w Polsce XIII-XV wieku. Uwagi problemowe, przedruk w: tegoż, Polskie rycerstwo średniowieczne. Wybór pism, Kraków 2002, s. 73-78.

${ }^{24}$ Dobrze ilustruje to przykład z dokumentu szlachty ziemi dobrzyńskiej z 1434 r., w którym pewne clenodium ma tylko jednego sygnatariusza, drugi sprawował bowiem urząd ziemski, a więcej dorosłych przedstawicieli w Dobrzyńskiem najwyraźniej nie było, zob. przyp. 39. 
zaś pierwszy zjazd generalny (sejm), w którym uczestniczyli wybierani na sejmikach posłowie ziemscy, kładzie się obecnie na $1468 \mathrm{r}^{25}$

Powołanie sformalizowanej reprezentacji szlachty nieurzędniczej na zjazd krakowski wynikało z ważnej problematyki, która miała tam być rozstrzygana. Wprawdzie Jan Długosz w Rocznikach wyraźnie go nie docenił i bardzo lakonicznie przedstawił tematykę obrad, podając tylko, że deliberowano o sposobach prowadzenia dalszej wojny z Krzyżakami wobec wygasania 24 VI 1433 r. rozejmu, po czym przeszedł od razu do relacji o zjeździe w Sandomierzu (początek marca 1433 r.) ${ }^{26}$. Bardziej wymowne są informacje wystawianych wtedy dokumentów. Chodzi tu o zatwierdzenie unii grodzieńskiej zawartej przez posłów królewskich 15 X 1432 r. z nowym wielkim księciem litewskim Zygmuntem Kiejstutowiczem, przy czym na zjeździe krakowskim wystawiono 3 I 1433 r. dwa dokumenty: właściwy królewski oraz drugi, również pod imieniem króla, ale zawierający poręczenie ze strony panów polskich ${ }^{27}$. Z kolei 9 I 1433 r. Władysław Jagiełło potwierdził przywilej jedlneński z 1430 r. (stąd określenie przywilej jedlneńsko-krakowski), gwarantowane przez bardzo sze-

${ }^{25}$ W. U r u s z c z a k, Poselstwo sejmowe w dawnej Polsce. Posłaniec, mandatariusz, poseł narodu, Czasopismo Prawno-Historyczne 61, 2009, z. 1, s. 53-56 (nie zgadzamy się jednak $\mathrm{z}$ autorem, że uczestniczący w rozliczaniu mennicy państwowej nuncii ziem, to tylko reprezentanci nieurzędniczej szlachty, która na zjeździe „grupowała się ziemiami”, raczej chodzi tu bowiem o reprezentantów szlachty poszczególnych ziem, którzy obok funkcji reprezentacyjnej przyjęli na siebie również funkcję kontrolną); t e n ż e, Poselstwo sejmowe w dawnej Polsce, w: Drogi i bezdroża nauk historyczno-prawnych, Bielsko-Biała 2010, s. 48-52; t e n ż e, Najstarszy sejm walny koronny „dwuizbowy” w Piotrkowie w 1468 roku, w: Narodziny Rzeczypospolitej. Studia z dziejów średniowiecza i czasów wczesnonowożytnych, t. II, Kraków 2012, s. 1033-1056 (tu także starsza literatura); o zjeździe krakowskim brak wzmianki w dziele Jana Długosza, który za to szeroko rozpisuje się o odbytych wcześniej w 1435 r. zjazdach w Brześciu Kujawskim, Sieradzu i Piotrkowie (Joannis Dlugossii Annales, lib. XI-XII, s. 152-155). Zjazd generalny w Krakowie znajduje potwierdzenie w dokumencie Władysława III z 7 X 1435 r., gdzie mowa, że poświadczana czynność prawna została dokonana de consilio consiliariorum et tutorum nostrorum in presenti convencione generali Cracouiensi nobiscum constitutorum (Akta grodzkie i ziemskie z Archiwum tak zwanego bernardyńskiego we Lwowie, t. V, wyd. O. Pietruski, X. Liske, Lwów 1875, nr 64; S.A. S r o k a, W. Z a w i t k o w s k a, Itinerarium króla Władysława III 1434-1444, Warszawa 2017, s. 41). Przedstawiona wyżej sytuacja każe z ostrożnością podchodzić do dzieła naszego dziejopisa jako wyroczni w sprawie listy zjazdów generalnych. Do początków sejmu polskiego w szerszej perspektywie zob. też J. D ü c k e r, Reichsversammlungen im Spätmittelalter. Politische Willensbildung in Polen, Ungarn und Deutschland, Ostfildern 2011, s. 25-90, oraz tejże (jako J. B u r k h a r d t), Frictions and Fictions of Community: Structures and Representations of Power in Central Europe, c. 1350-1500, The Medieval History Journal 19, 2016, nr 2, s. 197-200, 204, 206, 209-212, 216-219; t e j ż e, Vom Hoftag zur Reichsversammlung. Formen, Verfahren und Bedeutung politischer Versammlungen in Mitteleuropa, w: Stand und Perspektiven der Sozial- und Verfassungsgeschichte zum römisch-deutschen Reich. Der Forschungseinfluss Peter Moraws auf die deutsche Mediävistik, Affalterbach 2016, s. 111-132; t e j ż e, Spätmittelalterliche Reichsversammlungen in Polen und Deutschland, w: Frühneuzeitliche Reiche in Europa / Empires in Early Modern Europe. Das Heilige Römische Reich und Polen-Litauen im Vergleich, Wiesbaden 2016, s. 27-67.

${ }^{26}$ Joannis Dlugossii Annales, lib. XI-XII, s. 79-80.

${ }^{27}$ Akta Unii Polski z Litwą 1385-1791, wyd. S. Kutrzeba, W. Semkowicz, Kraków 1932, nr 58. 
rokie grono polskich możnych duchownych i świeckich ${ }^{28}$. Sprawy te były szeroko omawiane przez wcześniejszą literaturęe29.

Waga spraw omawianych na przełomie 1432 i 1433 r. w Krakowie pokazuje, że monarcha z całą pewnością potrzebował bardzo szerokiej akceptacji przedstawicieli narodu politycznego. Niewątpliwie z tego powodu wynikał nakaz, dotyczący stawienie się po dwóch starszych z każdego rodu z każdej ziemi Królestwa. Chodziło niewątpliwie o to, aby reprezentacja społeczna była jak najszersza pod względem stanowym oraz terytorialnym i nie ograniczała się tylko do możnowładztwa, z którego w większości rekrutowali się członkowie rady koronnej, średnich i niekiedy niskich urzędników ziemskich oraz zamożnej szlachty, zwyczajowo udających się na zjazdy generalne ${ }^{30}$.

Raport Mikołaja Steinchena jest drugą wzmianką źródłową z lat panowania Władysława Jagiełły, w której jest mowa o wezwaniu na zjazd z królem po dwóch przedstawicieli rodów rycerskich. Pierwsza z nich, zresztą starsza, pochodzi z tzw. Księgi formularzowej Stanisława Ciołka. Zawarta jest w pozbawionym daty rocznej liście Władysława Jagiełły do wielkiego księcia Witolda, gdzie mowa, o tym że na 11 listopada został zwołany zjazd w Wiślicy, podczas którego nobiscum mają zapaść ostateczne uchwały w sprawie zwalczania herezji ${ }^{31}$. Informacja ta znana była już Juliuszowi Bardachowi (datującemu ją za wydawcą na rok 1424) ${ }^{32}$ oraz Romanowi Grodeckiemu i Marii Koczerskiej, kładącymi ją na 1423 r. ${ }^{33}$ Należy jednak zauważyć,

${ }^{28}$ CEp. II, nr 212.

29 S. R o m a n, Konflikt prawno-polityczny 1425-1430 roku a przywilej brzeski, Czasopismo Prawno-Historyczne 14, 1962, z. 1, s. 89, 90; J. K u r t y k a, Tęczyńscy. Studium z dziejów polskiej elity możnowładczej w średniowieczu, Kraków 1997, s. 298, 299; J. S p e r k a, Szafrańcowie herbu Stary Koń. Z dziejów kariery i awansu w późnośredniowiecznej Polsce, Katowice 2001, s. 222-230; Z. W il k - W o ś, Władysław z Oporowa, s. 269, 270; G. B ł a s z c z y k, Dzieje stosunków polsko-litewskich, t. II, cz. 1, Poznań 2007, s. 693, 694; C.В. П о л е х о в, Наследники, s. 325, 326; W. Z a w i t k o w s k a, Walka polityczno-prawna o następstwo tronu po Władysławie Jagielle w latach 1424-1434, Rzeszów 2015, s. 301-305; A. S o c h a c k a, Jan z Czyżowa namiestnik Władysława Warneńczyka. Kariera rodziny Półkozów w średniowieczu, wyd. 2, Oświęcim 2016, s. 94-95; D. W r ó b e 1, Elity polityczne Królestwa Polskiego wobec problemu krzyżackiego w czasach Władysława Jagiełły, Lublin 2016, s. $473,474$.

30 J. B a rd a c h, Historia państwa i prawa Polski, t. I, wyd. 2, Warszawa 1964, s. 444445; t e n ż e, Początki sejmu, w: Historia sejmu polskiego, t. I, red. J. Michalski, Warszawa 1984, s. 14-15; t e n że, O stawaniu się sejmu polskiego we współczesnej historiografii, w: Parlamentaryzm w Polsce we współczesnej historiografii, Warszawa 1995, s. 31, 40, 41; W. U r u s z c z a k, Poselstwo sejmowe w dawnej Polsce. Posłaniec, s. 51; t e n ż e, Poselstwo sejmowe w dawnej Polsce, s. 49.

${ }^{31}$ Liber cancellariae Stanislai Ciołek, t. I, nr 8.

32 J. B a rd a c h, Historia państwa i prawa, t. I, s. 445; t e n ż e, Początki, s. 445.

${ }^{33}$ R. Grodec ki, Konfederacje w Polsce w XV w., Sprawozdania Polskiej Akademii Umiejętności 52, 1951, nr 10, s. 883; M. K o c z e r s k a, „Composicio clenodiorum” - fikcyjna konfederacja, w: Parlament, prawo, ludzie. Studia ofiarowane profesorowi Juliuszowi Bardachowi w sześćdziesięciolecie pracy twórczej, Warszawa 1996, s. 108. Dodajmy jeszcze, że J. Bardach i M. Koczerska uważali, że chodzi tu zjazd prowincjonalny szlachty małopolskiej, a R. Grodecki zjazd wiślicki uważał za ogólnopolski. 
że list ten, jak każdy przekaz z formularza, może budzić zastrzeżenia co do swej autentyczności ${ }^{34}$. Wątpliwości tego rodzaju miała już M. Koczerska, zwracając uwagę na to, że 11 XI 1423 r. król na pewno nie był obecny w Wiślicy, co stanowiło dla niej podstawę do ostrożnego podsumowania, że zjazd ów ,prawdopodobnie w ogóle nie odbył się" 35 . Dodajmy, że obecności Jagiełły w Wiślicy w listopadzie nie notuje jego itinerarium dla całej dekady lat dwudziestych XV w. ${ }^{36}$ Ostrożne wątpliwości wspomnianej badaczki można zatem wzmocnić. Istnieje znaczne prawdopodobieństwo, że cytowany list polskiego władcy nie jest przekazem wiarygodnym co do historyczności opisanego wydarzenia. Niezależnie od tego miarodajne musiały być wszakże opisane w nim realia, w tym sposób wyłaniania posłów. W przeciwieństwie wszakże do tego listu, publikowaną tu relację krzyżackiego szpiega należy uznać za jedyne całkowicie wiarygodne źródło, mówiące o królewskim wezwaniu na zjazd ogólnopolski po dwóch „starszych” z każdego rodu szlacheckiego. Nie wątpimy bowiem, że akurat ta informacja z raportu z początku grudnia 1432 r., zasługuje na pełne zaufanie. Przekonuje o tym jej szczegółowość i duże prawdopodobieństwo zaszłych wydarzeń: ogłoszenie królewskiego wezwania na zjeździe partykularnym przez urzędnika ziemskiego, sprawującego dowodnie wówczas urząd, którym był tytułowany, wezwanie na zjazd ogólnopolski (który rzeczywiście odbył się w podanym czasie i miejscu) reprezentacji w bardzo konkretnym kształcie, a także znaczna wiarygodność całego przekazu zakonnego informatora. Przeprowadzona przez nas jego analiza wskazuje bowiem, że Mikołaj Steinchen mylił się w swoim raporcie jedynie w przypadku śmierci Dobiesława Puchały ${ }^{37}$.

4. Wezwanie przez Władysława Jagiełłę reprezentacji nieurzędniczej szlachty w formie znanej z raportu Mikołaja Steinchena na zjazd krakowski miało swoje późniejsze konsekwencje. Można uznać raczej za pewnik, że w związku z nią pozostawały dokumenty szlachty brzeskiej (14 IV 1433) i dobrzyńskiej (25 I 1434), którymi wspomniane wspólnoty ziemskie gwarantowały obiór na tron polski po śmierci Jagiełły jednego z jego synów ${ }^{38}$. Jako sygnatariusze wystąpili w nich miejscowy

${ }^{34}$ Zob. M. K o c z e r s k a, Rzeczywistość i fikcja w formularzach polskich XV w., w: Literatura i kultura polskiego średniowiecza. Człowiek wobec świata znaków i symboli, Warszawa 1995, s. 23-38.

${ }^{35}$ M. K o c z e r s k a, „Composicio clenodiorum”, s. 108, przyp. 28.

${ }^{36}$ A. G ą s i o r o w s k i, Itinerarium, s. 93, 95, 98, 100, 103, 106, 108, 110, 113-115, 117 (za to niemal ,żelaznym” miejscem pobytu króla w tym terminie bywały Niepołomice, dość odległe od Wiślicy).

37 Zob. tekst źródłowy, przyp. 13, oraz zawarte niżej rozważania dotyczące starostów dobrzyńskich. Dodajmy jeszcze, że opisany w raporcie Steinchena niechętny stosunek Mazowsza do wojny z Zakonem w latach 1431-1435 odzwierciedlają także inne źródła, zob. W. S i e r a d z a n, Sąsiedztwo mazowiecko-krzyżackie w okresie przemian politycznych w Europie Środkowo-Wschodniej w latach 1411-1466, Toruń 1999, s. 43-56.

${ }_{38}$ Kodeks dyplomatyczny Polski, t. II, cz. 2, nr 576, 578. Wystawienie obu tych dokumentów było związane z przetargami o formę następstwa synów Władysława Jagiełły; obraz tych wydarzeń oraz dyskusję starała się ostatnio przedstawić W. Z a w itk ow s ka, Walka, co zwalnia nas z szerszego opisu tej problematyki. Jedną z form królewskich starań o następstwo tronu dla synów było skłanianie miast, wspólnot ziemskich i pojedynczych możnowład- 
biskup (dokument brzeski), urzędnicy ziemscy oraz po dwóch przedstawicieli każdego rodu szlacheckiego ${ }^{39}$. Powtarzało to na poziomie regionalnym zasadę znaną ze zjazdu krakowskiego. Pamiętajmy, że kształt dokumentów dotyczących następstwa tronu, wystawianych już od 1425 najpierw przez miasta, a począwszy od 1432 r. przez wspólnoty ziemskie, był narzucany przez kancelarię królewską, która w zakresie sygnatariuszy niesprawujących urzędów ziemskich w przypadku dokumentów brzeskiego (1433) i dobrzyńskiego (1434) przyjęła najwyraźniej rozwiązanie zastosowane podczas wspomnianego zjazdu ${ }^{40}$.

Warto przy tym wskazać, że w wystawionym przed zjazdem krakowskim analogicznym do brzeskiego i dobrzyńskiego (nawet w zakresie formularza) dokumencie szlachty poznańskiej (16 VI 1432), pierwszym wystawionym po istotnym dla sprawy następstwa tronu po Jagielle zjeździe sieradzkim z kwietnia 1432 r. ${ }^{41}$, obraz sygnatariuszy, ujętych zarówno w tekście, jak i znanych tylko z przywieszonej pieczęci, jest znacząco różny ${ }^{42}$. Obok biskupa poznańskiego oraz urzędników miejscowej hierarchii ziemskiej widzimy tam także wielu przedstawicieli szlachty nieurzędniczej, ale w ich doborze w ogóle nie można dopatrzeć się, jak sugerował to już dawniej J. Bieniak, schematu „rodowego" ${ }^{43}$. Warto jednak dodać, że pomimo tego także podczas sporządzania dokumentu poznańskiego pieczołowicie zadbano o heraldyczną, a co zatem idzie także i rodową, identyfikację niemal wszystkich sygnatariuszy, którzy przywiesili pod nim swoje pieczęcie, poprzez podanie na mocujących je paskach pergaminowych nie tylko personaliów dysponenta, ale także nazwy jego herbu ${ }^{44}$. Napisy te sporządzał zapewne jeden z pracowników kancelarii królewskiej, oddelegowany do ostatecznego wygotowania dokumentu. Może właśnie już wówczas w tej instytucji zaczął rodzić się pomysł sformalizowania reprezentacji szlachty nieurzędniczej w kierunku „rodowym” podczas najbliższych zjazdów generalnych i w kolejnych dokumentach hołdowniczych wystawianych przez wspólnoty ziemskie. Na pewno nie mamy z nią do czynienia jeszcze w dokumentach tego typu, wystawionych nieco wcześniej (1427)

ców do wystawiania dokumentów, w których deklarowali oni uznanie władzy najstarszego Jagiełłowica; zob. J. S p e r k a, Osobiste akty hołdownicze panów polskich z okresu panowania Władysława Jagiełł, w: Społeczeństwo Polski średniowiecznej, t. IX, Warszawa 2001, s. 221223, 235-251; t e n ż e, Szafrańcowie, s. 312-316.

39 Ściśle rzecz ujmując, wśród urzędników brzeskich znalazł się jeden dostojnik hierarchii inowrocławskiej, podstoli gniewkowski Krzesław z Morzyc (Urzędnicy kujawscy i dobrzyńscy XII-XV wieku. Spisy, opr. J. Bieniak, S. Szybkowski, Kórnik 2014, s. 196), a wśród niedzierżących urzędu sygnatariuszy dokumentu szlachty dobrzyńskiej był tylko jeden (Magnus z Osieka) z dwóch czynnych wówczas przedstawicieli rodu (czy raczej rodziny) Leblów, gdyż drugi (chorąży mniejszy dobrzyński Konrad z Osieka) znalazł się wśród urzędników ziemskich (tamże, s. 252).

${ }^{40}$ W. Z a w it k ow s k a, Walka, s. 86, 105-108, 291.

${ }^{41}$ Dyskusję literatury na temat zjazdu sieradzkiego podsumowały ostatnio: W. Z a w it k o w s k a, Walka, s. 288-293; A. S o c h a c k a, Jan z Czyżowa, s. 93, 94.

${ }^{42}$ Kodeks dyplomatyczny Wielkopolski, t. IX, nr 1289.

${ }^{43}$ Zob. J. B i e n i a k, Rody rycerskie jako czynnik struktury społecznej w Polsce XIII-XV wieku. Uwagi problemowe, przedruk w: tegoż, Polskie rycerstwo średniowieczne. Wybór pism, Kraków 2002, s. 81.

${ }^{44}$ Kodeks dyplomatyczny Wielkopolski, t. IX, nr 1289. Za wskazanie nam tego faktu pragniemy podziękować Prof. Tomaszowi Jurkowi z Instytutu Historii PAN. 
przez szlachtę ziem ruskich ${ }^{45}$. Należy uznać to za dodatkowy argument o powiązaniu formy reprezentacji na zjeździe krakowskim z tą odzwierciedloną przez dokumenty hołdownicze z Brześcia i Dobrzynia z lat 1433 i 1434.

Powyższy wniosek pozwala nam odnieść się do poglądów historyków, którzy „rodowy” charakter nieurzędniczej reprezentacji szlachty brzeskiej i dobrzyńskiej postrzegają jako dowód na bardzo duże znaczenie rodów szlacheckich w strukturze społecznej Polski czasów Władysława Jagiełły ${ }^{46}$. Wskazany związek pomiędzy dokumentami z 1433 i 1434 r. a królewskim wezwaniem na zjazd krakowski pozwala stwierdzić, że pojawiająca się tam rodowa reprezentacja nieurzędniczej szlachty nie wynikała najprawdopodobniej z oddolnej inicjatywy, a sam pomysł wyszedł od monarchy i jego otoczenia, zwłaszcza kancelarii. W takim świetle rzeczywisty obraz szlacheckich liderów wydają się przedstawiać wykazy sygnatariuszy dokumentów ruskich (1427) i dokumentu poznańskiego (1432) ${ }^{47}$. Rodowa reprezentacja szlachty nieurzędniczej w interesującym nas okresie, zaczynała powoli przegrywać w konfrontacji ze reprezentacją opartą na strukturach terytorialnych ${ }^{48}$. Wydaje się, że nawet dokumenty brzeski i dobrzyński były tu swego rodzaju kompromisem - nieurzędnicza szlachta była tam wprawdzie reprezentowana przez swoich rodowych seniores, ale występujących już jako element terytorialnej wspólnoty ziemskiej. Warto też wskazać, że form rodowej reprezentacji wspomnianej grupy szlacheckiej nie widać już później, po śmierci Władysława Jagiełły. Nie sposób się jej dopatrzeć w przypadku gwarantów pokoju brzeskiego, spisanego w 1436 r., gdzie występują głównie osoby wywodzące się z rodzin o dużym ponadlokalnym lub lokalnym znaczeniu politycznym, które nie uzyskały jeszcze nominacji na swoje pierwsze dostojeństwa ${ }^{49}$. Także cząstkowe badania grona nunciorum terrarum na zjeździe krakowskim z jesieni 1435 r. zaprzeczają ich rodowemu doborowi, a pokazują, że znaczna ich część sprawowała niższe urzędy ziemskie ${ }^{50}$. Reprezentacji rodowej szlachty nieurzędniczej nie znajdujemy

${ }^{45}$ F. P i e k o s i ń s k i, Jana Zamoyskiego notaty heraldyczno-sfragistyczne, w: tegoż, Studia, rozprawy i materiały z dziedziny historii polskiej i prawa polskiego, t. VI, Kraków 1907, s. 26-33, 69-85, 99-108; Z Jana Zamoyskiego inwentarza Archiwum Koronnego. Materiały do dziejów Rusi i Litwy w XV wieku, opr. O. Halecki, w: Archiwum Komisji Historycznej, t. XII, cz. 1, Kraków 1919, s. 179-193; zob. o tym J. K u rty k a, Z dziejów walki szlachty ruskiej o równouprawnienie: represje lat 1426-1427 i sejmiki roku 1439, Roczniki Historyczne 66, 2000, s. 91.

${ }^{46}$ Np. J. B i e n i a k, Clans de chevalerie en Pologne du XIIIe au XVe siècle, w: Famille et parenté dans l'Occident médiéval, Rome 1977, s. 327-328; t e n ż e, Rody rycerskie, s. 81-82; t e n ż e, Heraldyka Polska przed Długoszem. Uwagi problemowe, przedruk w: tegoż, Polskie rycerstwo średniowieczne (jak w przyp. 43), s. 83 (ród jako „podmiot prawa”).

${ }^{47}$ Zdania, że forma reprezentacji szlacheckiej w dokumencie poznańskim z 1432 r. lepiej oddawała ,aktualny stosunek sił na sejmiku”, choć system przyjęty na Kujawach Brzeskich i w ziemi dobrzyńskiej był bardziej demokratyczny, ale i bardziej tradycyjny, był J. B i e n i a k, Rody rycerskie, s. 81-82.

48 Tamże, s. 80-81.

${ }^{49}$ D. W r ó b e 1, Elity polityczne, s. 495, 496.

50 S. S z y b k o w s k i, Nowe źródła do dziejów polsko-krzyżackich rokowań w Brześciu Kujawskim w grudniu 1435 r., Ziemia Kujawska 16, 2003, s. 86, 87; t e n ż e, Szlacheckie elity urzędnicze we wspólnocie terytorialnej w późnym średniowieczu (na przykładzie środkowopolskim), w: Człowiek w średniowieczu. Między biologią a historią, Łódź 2009, s. 116, 117. 
także w wystawionych w 1439 r. dokumentach szlachty ruskiej i podolskiej dotyczących elekcji Władysława III, opartych o formularz bardzo zbliżony do formularza dokumentów poznańskiego, brzeskiego i dobrzyńskiego ${ }^{51}$.

Ostatnie badania dowodzą, że również uznawana za „koronę" ${ }^{52}$ wszystkich źródłowych dowodów na szczególne znaczenie polityczne rodów rycerskich w pierwszej połowie XV w. tzw. Composicio clenodiorum jest najprawdopodobniej fikcyjnym tekstem formularzowym ${ }^{53}$. Przypomnijmy też formularzowy najpewniej list Jagiełły do Witolda (ze wzmianką o rodowej reprezentacji na zjazd wiślicki). Powstanie obu tych tekstów w kręgu kancelarii koronnej końcowego okresu rządów Jagiełły (list) lub w latach po jego śmierci (Composicio $)^{54}$, zdaje się wskazywać, że wśród jej personelu panowało przekonanie o dużym znaczniu szlacheckiej organizacji rodowej. Zapewne to właśnie z tego grona wyszła rada, która skłoniła króla Władysława do żądania, aby na zjazd krakowski przybyła nieurzędnicza reprezentacja szlachecka w kształcie „rodowym”. Uznać to należy za jedną z dróg poszukiwań najodpowiedniejszej formy reprezentacji szlachty szeregowej na zjazdach generalnych. Wydaje się, że kolejne etapy wyznaczają tu dokumenty hołdownicze z Rusi (1427), dokument poznański (1432), wreszcie wymagana przez króla forma reprezentacji na zjeździe krakowskim oraz dokumenty brzeski (1433) i dobrzyński (1434). Proces zanikania reprezentacji rodowej zamknął się w czasach rządów opiekuńczych podczas niepełnoletniości Władysława III (1434-1438), nie widać jej bowiem na licznie odbywanych wówczas zjazdach ogólnopolskich i partykularnych. Nawet wówczas jednak struktury rodowe były uważane za istotny element społeczeństwa szlacheckiego (jak wskazuje powstanie fikcyjnej Composicio clenodiorum $)^{55}$.

Zanik rodowej reprezentacji stanowej wynikać mógł przynajmniej po części z kolizji występujących w niej założeń. $Z$ jednej strony miała bowiem zapewnić szeroki udział w zjazdach stanowych szlachty nie sprawującej urzędów ziemskich, z drugiej jednak grupa ta miała być reprezentowana przez swoich seniores. Za „starszych” uważano jednak z reguły właśnie urzędników ziemskich ${ }^{56}$. Mogło to powodować określone trudności z wyborem ,zastępczych” seniorów i prowadzić do wyłaniania reprezentacji złożonej z osób przypadkowych i politycznie niewyrobionych. Nie musiało to być zresztą niekorzystne dla monarchii, starającej się o zachowanie mocnej pozycji w grze z narodem politycznym - może właśnie tu tkwiła jedna z przyczyn krótkotrwałego pojawienia się tej formy reprezentacji stanowej w końcowych latach panowania króla Jagiełły, a zanik w czasie, kiedy pozycja małoletniego króla uległa osłabieniu ${ }^{57}$.

${ }^{51}$ F. P i e k o s i ń s k i, Jana Zamoyskiego notaty, s. 43-46; Z. S p i e r a ls k i, Z dziejów Archiwum Koronnego Krakowskiego. Kopiariusz Jana Łaskiego (około 1505), cz. I, Studia Źródłoznawcze 24, 1979, s. 136-137; J. K u rty k a, Z dziejów, s. 104-109, 111-119.

52 Tak J. B i e n i a k, Heraldyka, s. 83.

${ }_{53}$ M. K o c z e r s k a, „Composicio clenodiorum”, s. 104-111.

${ }^{54}$ Liber cancellariae Stanislai Ciołek, t. II, dodatek B, s. 238-241; M. K o c z e r s k a, „Composicio clenodiorum”, s. 109-110, powstanie tego tekstu datuje orientacyjnie na rok 1438 .

${ }_{55}$ M. K o c z e r s k a, „Composicio clenodiorum”, s. 109-111.

56 Zob. uwagi S. S z y b k o w s k i e g o, Szlacheckie elity urzędnicze, s. 103-124.

57 Raczej nie należy łączyć rodowej formy reprezentacji szlachty brzeskiej i dobrzyńskiej ze specyfiką tego regionu. Dość dobrze zachowany dla Kujaw Brzeskich zasób ksiąg sądowych 
5. Komentarza wymaga również problem występującego w raporcie starosty bobrownickiego (czyli dobrzyńskiego), którego ojciec właśnie zmarł. Ostatnio przyjmuje się, że starostą dobrzyńskim (bobrownickim) na początku lat trzydziestych XV stulecia, aż do śmierci 4 X 1432 r., był kasztelan lubelski Jan ze Szczekocin, po nim zaś urząd ten objął podłowczy dobrzyński Piotr z Działynia, notowany po raz pierwszy 30 I 1433 r. ${ }^{58}$ Starosty z grudniowej relacji Steinchena nie sposób jednak identyfikować z Piotrem, ponieważ ojciec tegoż, Mikołaj z Kutna, zmarł już w 1400 r. ${ }^{59}$ Wydaje się zatem, że houptman to jeden z synów Jana ze Szczekocin, który wyręczał sędziwego ojca w zarządzaniu starostwem i rezydował w Bobrownikach także po jego śmierci wobec braku nowego nominata królewskiego. Czas pojawienia się nowego starosty pozwala przypuszczać, że decyzję o jego mianowaniu Władysław Jagiełło podjął dopiero na zjeździe krakowskim, na który syn Jana, zgodnie z raportem Mikołaja Steinchena, również się wybierał ${ }^{60}$. Praktyka wyręczania się synami w zarządzie starościńskim była znana także w późniejszym okresie. Wiadomo np., że w imieniu starosty dobrzyńskiego Mikołaja Kościeleckiego ze Skępego zarządzał starostwem jego syn Wincenty i był nawet tytułowany starostą ${ }^{61}$.

Spośród synów kasztelana Jana, jako jego zastępcę na starostwie dobrzyńskim należy raczej wykluczyć Dobiesława (późniejszego podstolego lubelskiego, a następnie sandomierskiego) - ten bowiem w 1431 r. zarządzał tenutą olsztyńską, a w 1432 r. (także w grudniu) był aktywny w Małopolsce ${ }^{62}$. W grę wchodzą zatem pozostali synowie - Piotr Woda (późniejszy podkanclerzy Królestwa) oraz Jan młodszy (późniejszy podkomorzy lubelski i stolnik sandomierski) - ale nie potrafimy stwierdzić, który mógł być zarządcą starostwa ${ }^{63}$.

nie wskazuje bowiem, by instytucje rodowe były tam silniejsze niż w innych ziemiach Królestwa Polskiego.

${ }^{58}$ Urzędnicy kujawscy i dobrzyńscy, s. 196.

59 S. S z y b k ow s k i, Kościeleccy ze Skępego herbu Ogon i ich protoplaści. Studium z dziejów późnośredniowiecznej rodziny możnowładczej, Gdańsk 2018, s. 82.

${ }^{60}$ Zgodnie z ustaleniami S. J ó ź w i a k a (Wywiad, s. 162; Na tropie, s. 65) zmiana na urzędzie starosty dobrzyńskiego (odejście syna Jana ze Szczekocin i zastąpienie go przez Piotra z Działynia), o mało nie zakończyła się zdemaskowaniem Mikołaja Steinchena, został on bowiem nieco przed 6 II 1433 r. wezwany do Bobrownik, gdzie postawiono mu zarzut spiskowania z Krzyżakami, którym miał radzić, aby napadli na zamek bobrownicki, wykorzystując okoliczność zmiany starosty. Utrudniło mu to kontakty z pruskimi mocodawcami, ponieważ był przez jakiś czas bacznie obserwowany, ale swej szpiegowskiej pracy nie zaniechał.

${ }^{61}$ Podobnie było w przypadku starostwa brodnickiego formalnie dzierżonego przez Mikołaja (S. S z y b k o w s k i, Kościeleccy, s. 286-288).

${ }_{62}$ R. T r a w k a, Szczekocki Dobiesław, w: Polski słownik biograficzny (dalej cyt.: PSB), t. XLVII (2010-2011), s. 236; J. L a b e r s c h e k, Początki i rozwój miasta Szczekociny do końca XV w. Uwagi do genealogii Szczekockich herbu Odrowąż, w: Patientia et tempus. Księga jubileuszowa dedykowana doktorowi Marianowi Korneckiemu, Kraków 1999, s. 112; K. N a b i a ł e k, Starostwo olsztyńskie od XIV do połowy XVII wieku, Kraków 2012, s. $359-360$.

${ }^{63}$ K. O ż ó g, Piotr Woda ze Szczekocin, w: PSB XXVI (1981), s. 434-436; R. Tr a w k a, Szczekocki Jan, w: PSB XLVII (2010-2011), s. 238-243. 
6. Publikowany raport okazuje się ważnym źródłem także do poznania wydarzeń, które jesienią 1432 r. rozgrywały się daleko od północnej Polski, na pograniczu polsko-litewskim, przyciągając uwagę króla Władysława Jagiełły i jego otoczenia. Chodzi tu o datowanie zajęcia Łucka przez wojska królewskie w toku kampanii podjętej już po obaleniu wielkiego księcia litewskiego Świdrygiełly (w nocy z 31 VIII na 1 IX 1432 r. $)^{64}$. Dotychczas zgodnie uznawano, że terminum ante quem zdobycia Łucka przez Polaków wyznacza przywilej Jagiełłowy dla ziemi łuckiej z 30 X 1432 r., wystawiony we Lwowie ${ }^{65}$. Przykładowo, G. Błaszczyk przyjmował, ,że u genezy tego przywileju leżała propozycja samych Wołynian, którzy udali się do króla Władysława Jagiełły i zaproponowali mu poddanie się jemu i Królestwu Polskiemu" ${ }^{\text {. }}$. Trudności sprawiało natomiast dokładniejsze wyznaczenie chronologii wydarzeń na podstawie wiadomości z listów krzyżackich, ponieważ dostojnicy krzyżaccy starali się jak najszybciej przekazać do zwierzchnika Zakonu wszystkie informacje dotyczące Polski i Litwy, nie dbając we właściwy sposób o ich rzeczywistą sekwencję. Raport Steinchena pozwala jednak je uporządkować i uściślić ich chronologię. Znamienny jest fakt, że o nieudanych próbach zdobycia zamku łuckiego Steinchen donosił, informując jednocześnie o działaniach Jana z Lichenia, który znajdował się u boku Jagiełły w chwili wystawieniu przywileju królewskiego dla ziemi łuckiej z $30 \mathrm{X}$ 1432 r. Wydaje się zatem pewne, że do zdobycia zamku łuckiego doszło dopiero po tej dacie, czyli w listopadzie ${ }^{67}$. Zwraca uwagę też inna okoliczność - brak w wspomnianym przywileju jakiejkolwiek wzmianki o pertraktacjach z mieszkańcami ziemi łuckiej. Nie występują oni również w obszernej liście świadków tego dokumentu. Przewidywane w nim ustępstwa nie były zatem najprawdopodobniej wynikiem negocjacji z mieszkańcami tej ziemi ${ }^{68}$. Raczej chodziło o jednostronne działanie ze strony

${ }^{64}$ С.В. П о л е х о в, Наследники, s. 241-258, 314-317.

${ }^{65}$ CEp. I, nr 82; Б. Бу ч и н с ь к и й, Кілька причинків, s. 137-139.

${ }^{66}$ G. B ł a s z c zy k, Dzieje stosunków, t. II/1, s. 685; z literatury wcześniejszej zob. A. L e w i c k i, Powstanie Świdrygiełły. Ustęp z dziejów unii Litwy z Koroną, Kraków 1892, s. 156-157; М.С. Гр уш е в с ь к и й, Історія України-Руси, т. IV, Львів 1907, s. 211-212; O. H a l e c k i, Dzieje unii jagiellońskiej, t. I, Kraków 1919, s. 302-305; L. K o l a n k o w s k i, Dzieje Wielkiego Księstwa Litewskiego za Jagiellonów, t. I, Warszawa 1930, s. 193, natomiast Б. Бу ч и н с ь к и й, Кілька причинків, s. 124-127, datował na ten czas rozejm łucczan z Koroną, który, jak ustalono później, zawarto latem $1433 \mathrm{r}$.

${ }^{67}$ Dopiero 12 grudnia donosił o tym wielkiemu mistrzowi komtur Ostródy, powołując się na informacje otrzymane od Janusza Sztembarskiego (GSPK, OBA, nr 6276). Nie przeczy temu udział niektórych uczestników oblężenia Łucka - wiemy o tym w przypadku Jana Mężyka z Dąbrowy i Jana z Sienna - w walkach pod Bracławiem, które na pewno nie ograniczały się do bitwy nad rzeką Murachwą stoczonej 30 XI 1432 r. (Joannis Dlugossii Annales, lib. XI-XII, s. 73-77; Zbiór dokumentów małopolskich, wyd. I. Sułkowska-Kuraś, S. Kuraś, t. VII, Wrocław 1975, nr 2117; Liv-, Est- und Curländisches Urkundenbuch, Abt. I, t. VIII, wyd. H. Hildebrand, Riga-Moskau 1884, nr 651; GSPK, OBA, nr 6291; zob. też C.В. П о л е х о в, Наследники, s. 314-318). Nie miał zatem racji O. Н a l e c k i, Dzieje unii, t. I, s. 304, pisząc, iż warunki dopiero co zawartej z Zygmuntem Kiejstutowiczem unii grodzieńskiej zrewidowano, gdy „we Lwowie jeszcze nie można było wiedzieć, że w Grodnie przyznano tę ziemię Kiejstutowiczowi”.

${ }^{68}$ Nie można tego jednak całkowicie wykluczyć, ponieważ przed wystawieniem przywileju miało miejsce spotkanie króla z ziemianami oleskimi, dla których Jagiełło wystawił przywilej 18 X 1432 r., opublikowany przez A. Prochaskę pod błędną datą roczną (1431), na podstawie 
Nowe źródło do dziejów kształtowania się polskiej reprezentacji stanowej 147

króla i jego otoczenia, liczących na skłonienie obrońców Łucka do poddania się ${ }^{69}$. Zwraca uwagę, że przywilej był później przechowywany w Archiwum Koronnym Krakowskim, przy czym nie został unieważniony, w przeciwieństwie do Jagiełłowego przywileju dla całego Wielkiego Księstwa Litewskiego z 15 X 1432 r. $^{70}$ Nie był również potwierdzany przez kolejnych wielkich książąt litewskich. Być może wynikło to z faktu, że ziemia łucka pozostawała pod władzą króla Władysława bardzo krótko, bo tylko do wiosny 1433 r. ${ }^{71}$ Nie można zatem wykluczyć, że przywilej ten nigdy nie został przekazany odbiorcom. Może jednak znalazł się w stolicy ziemi łuckiej, a kiedy ta ponownie przeszła pod władzę Świdrygiełły, jakiś polski urzędnik zabrał go ze sobą, co doprowadziło w efekcie do zdeponowania dokumentu w archiwum królewskim $^{72}$. Sprawy tej nie potrafimy jednoznacznie rozstrzygnąć.

7. Dane źródłowe dotyczące działalności Mikołaja Steinchena pozwalają przypuszczać, że był on potencjalnie bardzo groźnym szpiegiem. Swobodnie poruszał się wśród elit szlacheckich ziemi dobrzyńskiej i Mazowsza. Za szczególnie niepokojące należy uznać, że swojego wspólnika w szpiegowskim procederze a zarazem brata, Bartolda, udało mu się umieścić w otoczeniu podkanclerzego Władysława Oporowskiego, współkierownika kancelarii koronnej, jednego z politycznych centrów, w których kształtowano polską politykę zagraniczną i wewnętrzną. Brak jednak źródeł uniemożliwia ocenę tego, w jaki sposób wiedza pozyskana od Steinchenów wpływała na bieżące posunięcia Krzyżaków w gorącym okresie 1431-1435. Może dalsze badania pozwolą na uzupełnienie tego obrazu.

Nieoczekiwaną wartością dla dziejów wewnętrznych Polski schyłku rządów króla Władysława Jagiełły jest niewątpliwie pochodząca z publikowanego tu raportu informacja o postulowanej przez polskiego monarchę formie reprezentacji szlachty

mylnie datowanej i uszkodzonej szesnastowiecznej kopii (A. P [ r o c h a ] s k a, Przebaczenie królewskie ziemianom oleskim w 1431 r., Kwartalnik Historyczny 9, 1895, s. 43-45). Pełen tekst: Warszawa, Archiwum Główne Akt Dawnych (dalej cyt.: AGAD), Metryka Koronna 36, s. 939-940; 70, k. 288v-289v.

${ }^{69}$ Zauważono już, że przywilej Jagiełły dla ziemi łuckiej i jego niedoszły przywilej dla Wielkiego Księstwa Litewskiego z 15 X 1432 r. ,pod względem treści mają - - wiele wspólnego" (G. B ła s z c z y k, Dzieje stosunków, t. II/1, s. 685).

70 Jeszcze w 1767 r. była pod nim przywieszona wielka pieczęć królewską (Biblioteka XX. Czartoryskich, rkps 237, nr 127, k. 163-164). Noty Archiwum Koronnego Krakowskiego pochodzą z XVI-XVIII w., przywilej występuje też w inwentarzach archiwalnych z tego czasu (AGAD, Nabytki niedokumentowe Oddziału I, sygn. 30, k. 53; AGAD, Archiwum Zamoyskich, sygn. 33, s. 450-451, 698 nowej paginacji; AGAD, Varia Oddziału I, sygn. 57, k. 221; Inventarium omnium et singulorum privilegiorum, litterarum, diplomatum, scripturarum et monumentorum quaecunque in Archivo Regni in Arce Cracoviensi continentur, wyd. E. Rykaczewski, Lutetiae Parisiorum 1862, s. 271; AGAD, Tzw. Metryka Litewska, sygn. VIII B 5, k. 242-242v).

${ }^{71}$ С.В. П о л ех о в, Наследники, s. 336-337.

${ }^{72}$ Niestety, nie wiadomo nic o zarządzie Łuckiem w składzie Królestwa Polskiego w tym czasie. Możemy posłużyć się analogią z lat 1437-1439, gdy źródła wspominają o urzędnikach polskich w ziemi łuckiej; z drugiej strony list komtura Ostródy do wielkiego mistrza z 23 IV 1433 r. sugeruje, że jakąś władzę sprawował tam kniaź Aleksander Nos, prawnuk Narymunta Giedyminowicza, działający na Wołyniu już pod koniec 1430 r. (С.В. П о л е х о в, Наследники, s. 336-337, 423-431). 
nieurzędniczej na zjazd krakowski z przełomu 1432 i 1433 r. Jest to jedna z dwóch, znanych dotąd, wzmianek o rodowym charakterze reprezentacji stanowej. W przeciwieństwie wszakże do informacji z formularzowego listu Jagiełly do Witolda z 1423 r. dotyczy ona zjazdu generalnego, a przede wszystkim nie można mieć żadnych uwag co do jej wiarygodności. Wydaje się, że, biorąc pod uwagę stosunkowe ubóstwo danych źródłowych dotyczących kształtowania się parlamentaryzmu polskiego w tym czasie, wzmianka ta stanie się na pewno elementem kolejnych analiz.

\section{TEKST ŹRÓDŁOWY}

Or:: GSPK, OBA, nr 6304 (dawniej: XXIX 101/b), papier 300 $\times 227 \mathrm{~mm}$, bez filigranu, prawy margines silnie uszkodzony (postrzepiony), ubrudzony, podklejony na odwrociu; in dorso notatka rękq i atramentem z XIX w.: Hussiten, pod tekstem okragla pieczęć Archiwum Królewieckiego. - Reg.: RHD I/1, nr 6304. - Uwaga: Wydanie przygotowane na podstawie propozycji M. Thumsera, Zehn Thesen zur Edition deutschsprachiger Geschichtsquellen (14.-16. Jahrhundert), w: Editionswissenschaftliche Kolloquien 2005/2007. Methodik-Amtsbücher - digitale Edition - Projekte, Toruń 2008, s. 13-19.

Wisset, gnediger here, wy daz itczunt gross czweytracht in Polan ist: dy eynen rathen czu frede, dy andern czu krige. Sunder vor vore sy kunnen obil krig anheben, wen sy sich sere uff dy Behemen vorlossen haben, alz sy sich mit en geeynyget haben; sunder sy kunnen en nicht tzu holfe komen, wen dy konigynne von Ungern ${ }^{l}$ grosse manschaft czu hauffe brocht hot weder dy Behemen, unde dez vorchten sich och sere dy Polan unde haben sorge, man welle sy och angeen. Och hat der herczog von Ossterrich ${ }^{2}$ vil volkes weder dy Behemen unde en vaste schaden gethon, daz ir euch nicht vor den Behemen dorffet vorchten, wen si euch nymmer schaden mogen. Och claget der koning in allen landen obir den Orden, sunder man nicht den bothen geloubet, unde sind vor nichte gehalden. Och hat der konig ken Lutzke ${ }^{3}$ vaste banir gesand, daz huss czu gewynnen, unde sy alles nicht schaffen. Och hat nu am montage der woywode her Jon Lichinsky ${ }^{4}$ eynen tag gehalden czu Beberern ${ }^{5}$ von sendunge dez koniges unde gesayt, daz alle land ken der Crone von Polan offsten unde daz der konig gebut, daz von ittzlichem schilde uss itzlichem gebythe tzwene dy eldesten ken Crokow uff Wynachten [25 XII] komen, do wirt man allir sachen unde dinge eyn ende wissen unde theydingen; unde do werden der rot von Ungern, der rot von Litwen, der rot uss der Margke unde och Behemen, unde do habe ich Bertholde $^{6}$ hyngesant $^{a-a}$; in virtzen thagen noch Wynachten sollet ir allis dirfaren, voruffe ys sten zal. Och wisset, daz dy Polan gantz frede halden wellen biss tzu zynthe Johannes tag [24 VI]. Och zindt dy Maser by ennander gewest unde synt alle doruff bestanden, bittende dy hertzogen ${ }^{7}$, daz sy tzu frede reden adder helffen, unde ap en der konig adder syn rot nicht volgen welde, daz sy thun, alz sy so lange gethon haben, alz ir hern, unde bestellen mit deme Orden, daz sy mit im eynen vesten frede haben mogen, unde haben och den bisschoff ${ }^{8}$ dorumme gebethen, daz her rote den hertzogen tzu frede; zo sage ich euch, daz der bisschoff gantz allis, dorinne der Orden syner begert, worinne her sich erbeyten zal, gerne um dez Ordens wille thun wil unde frunt syn. Och wisset, daz der houptman von Beberern tzum konige getzogen 
ist, unde syn vater thot ist ${ }^{9}$; waz her czytunghe brenget, dy sollet ir wol wissen. Och schrybet alleweyge unde nu och in disser czyt der konig deme houptmanne, daz her den Orden nicht beschedige, unde ap dez Ordens leuthe icht schade der Krone tethe, daz her sich nicht solde rechen, wen allir schade, der ye gethon were in deme frede, der vor Lutzke ${ }^{10}$ bestetiget wart, solde unde muste werden von beiden teylen betzalt. Och, gnediger here, wisset, daz ich keyns vorsumen wil, daz euch schaden mag czu taghe unde nachte, ir sollet wol by tzyten gewarnet werden, unde solde ich dorumme den tot lyden, deme ys doch [s. 2] gar noe gewest ist. Och ist Berthold allis by deme undirkentzeler ${ }^{l l}$ unde vorsumet keyns czu wissen; syet ane tzwyffel, wir wellen euch keyns vorsumen, unde ich habe mich dorumme czum Gorßen ${ }^{12}$ geleget unde von mym hern bisschoffe von Plotzke daz ampt entpfangen, uff der ir yo by tzyten alle ding wissen sollet, syt myn gnediger here. Ouch ist Puchale thot ${ }^{13}$. Sunder der konig ist krang gewest unde ist ittzunt gesunt unde tzuet ittzunt von der Lemborg ken Crokow ${ }^{14}$.

${ }^{a-a}$ Najprawdopodobniej skreślone i zamazane: by.

${ }^{1}$ Barbara Cylejska, córka hrabiego Hermana II Cylejskiego, druga żona (od 1406) Zygmunta Luksemburskiego, zm. 1451 (Allgemeine deutsche Biographie, t. II, s. 48-49; Neue deutsche Biographie, t. I, s. 581; D. Dvořáková, Barbara von Cilly. Die Schwarze Königin (1392-1451). Die Lebensgeschichte einer ungarischen, römisch-deutschen und böhmischen Königin, Bratislava 2017). $\quad 2$ Albrecht II Habsburg, ksiaże austriacki od 1404, margrabia morawski od 1423, król rzymski, węierski i czeski od 1438, zm. 1439 (Allgemeine deutsche Biographie, t. I, s. 227-229; Neue deutsche Biographie, t. 1, s. 154). ${ }^{3}$ Euck na Wotyniu. ${ }^{4}$ Jan z Lichenia $i$ Gosławic herbu Godziemba, kasztelan śremski 1422-1430, wojewoda brzeski 1430-1448, starosta brzeski 1433-1438 (A. Gąsiorowski, Licheński Jan, w: PSB XVII (1972), s. 294-295; Urzędnicy kujawscy i dobrzyńscy, s. 192, 214, 237; Urzędnicy wielkopolscy XII-XV wieku. Spisy, red. A. Gąsiorowski, Wroctaw 1985, s. 109, 163, 190). ${ }^{5}$ Bobrowniki, w ziemi dobrzyńskiej, dawniej miasto, siedziba starostów dobrzyńskich. ${ }^{6}$ Bartold Steinchen, zob. w tekście, przyp. 7. ${ }^{7}$ Chodzi tu o władająych Mazowszem Płockim synów Siemowita IV: Siemowita V, Kazimierza II $i$ Władysława I oraz panujacego we wschodniej części Mazowsza Bolesława IV, wnuka Janusza I Starszego (K. Jasiński, Rodowód Piastów mazowieckich, Warszawa 1998, s. 106-111, 125-130, 133-136, 157-160). $\quad{ }^{8}$ Stanisław Pawtowski h. Pierzchała, biskup płocki 1425-1439 (T. Żebrowski, Pawłowski Stanisław, w: PSB XXV (1980), s. 510-513; A. Radzimiński, Prałaci i kanonicy kapituly katedralnej płockiej w XIV i I pot. XV w. Studium prozopograficzne, t. I, Toruń 1991, s. 131-132). ${ }^{9}$ Zob. w tekście, przyp. 62, 63. ${ }^{10}$ Chodzi o kończacy walki pod Łuckiem rozejm, tzw. czartoryski, uzgodniony 26 VIII a opieczętowany przez strone polska 2 IX 1431 r. (S. Polechow, S. Szybkowski, Królewski dokument rozejmu ze Świdrygietła z 20 VIII 1431 roku, Roczniki Historyczne 83, 2017, s. 142-144). " "Wtadysław Oporowski h. Sulima, zm. 1453, sekretarz królewski 1426-1427, podkanclerzy Królestwa Polskiego 1428-1434, biskup włocławski 1433-1448, arcybiskup gnieźnieński 1448-1453 (A. Gassiorowski, Oporowski Władysław, w: PSB XXIV (1979), s. 142-144; Z. Wilk-Woś, Władysław z Oporowa). ${ }^{12}$ Górzno, miasto biskupów płockich w ziemi dobrzyńskiej, obecnie gmina loco, powiat brodnicki, województwo kujawsko-pomorskie. ${ }^{13}$ Dobiesław Puchała z Węier h. Wieniawa, starosta gniewkowski 1418-1419, bydgoski 1431-1441, aktywny współkombatant czeskich husytów (Z.H. Nowak, Puchała Dobiestaw, w: PSB XXIX (1986), s. 323-325; Urzędnicy kujawscy $i$ dobrzyńscy, s. 216, 218, 244). Informacja o jego śmierci jest nieprawdziwa, możliwe jednak, że dotarła ze Ślaska, gdzie Dobiesław wspierat wówczas zbrojnie husytów, ale nie wiodto mu się najlepiej. ${ }^{14}$ Lwów i Kraków. Informacja zgodna z itinerarium króla Władysława Jagietly z grudnia 1432 r. (A. Gąsiorowski, Itinerarium, s. 121, 122). 


\section{BIBLIOGRAFIA}

Bardach J., Historia państwa i prawa Polski, t. I, wyd. 2, Warszawa 1964.

Bardach J., O stawaniu się sejmu polskiego we współczesnej historiografii, w: Parlamentaryzm w Polsce we współczesnej historiografii, Warszawa 1995.

Bardach J., Początki sejmu, w: Historia sejmu polskiego, t. I, Warszawa 1984.

Bieniak J., Clans de chevalerie en Pologne du XIIIe au XVe siècle, w: Famille et parenté dans l’Occident médiéval, Rome 1977.

Bieniak J., Heraldyka Polska przed Długoszem. Uwagi problemowe, przedruk w: tegoż, Polskie rycerstwo średniowieczne. Wybór pism, Kraków 2002.

Bieniak J., Rody rycerskie jako czynnik struktury społecznej w Polsce XIII-XV wieku. Uwagi problemowe, przedruk w: tegoż, Polskie rycerstwo średniowieczne. Wybór pism, Kraków 2002.

Błaszczyk G., Dzieje stosunków polsko-litewskich, t. II, cz. 1, Poznań 2007.

Burkhardt J., Frictions and Fictions of Community: Structures and Representations of Power in Central Europe, c. 1350-1500, The Medieval History Journal 19, 2016, nr 2.

Burkhardt J., Vom Hoftag zur Reichsversammlung. Formen, Verfahren und Bedeutung politischer Versammlungen in Mitteleuropa, w: Stand und Perspektiven der Sozial- und Verfassungsgeschichte zum römisch-deutschen Reich. Der Forschungseinfluss Peter Moraws auf die deutsche Mediävistik, Affalterbach 2016.

Burkhardt J., Spätmittelalterliche Reichsversammlungen in Polen und Deutschland, w: Frühneuzeitliche Reiche in Europa / Empires in Early Modern Europe. Das Heilige Römische Reich und Polen-Litauen im Vergleich, Wiesbaden 2016.

Dücker [Burkhardt] J., Reichsversammlungen im Spätmittelalter. Politische Willensbildung in Polen, Ungarn und Deutschland, Ostfildern 2011.

Dvořáková D., Barbara von Cilly. Die Schwarze Königin (1392-1451). Die Lebensgeschichte einer ungarischen, römisch-deutschen und böhmischen Königin, Bratislava 2017.

Gąsiorowski A., Itinerarium króla Władysława Jagiełły 1386-1434, wyd. 2, Warszawa 2015.

Gąsiorowski A., Licheński Jan, w: Polski słownik biograficzny, t. XVII (1972).

Gąsiorowski A., Oporowski Władysław, w: Polski słownik biograficzny, t. XXIV (1979).

Grabowski J., Potęga służb specjalnych. Rola wywiadu i kontrwywiadu państwa zakonnego w Prusach, Zapiski Historyczne 72, 2007.

Grodecki R., Konfederacje w Polsce w XV w., Sprawozdania PAU 52, 1951, nr 10.

Guldon Z., Powierski J., Podziały administracyjne Kujaw i ziemi dobrzyńskiej w XIII-XIV wieku, Warszawa-Poznań 1974.

Halecki O., Dzieje unii jagiellońskiej, t. I, Kraków 1919.

Jóźwiak S., Wywiad i kontrwywiad w państwie zakonu krzyżackiego w Prusach. Studium nad sposobami pozyskiwania i wykorzystywaniem poufnych informacji w późnym średniowieczu, Malbork 2004.

Jasiński K., Rodowód Piastów mazowieckich, Warszawa 1998.

Jóźwiak S., Na tropie średniowiecznych szpiegów. Wywiad i kontrwywiad w polsko-litewsko-krzyżackich stosunkach politycznych w XIV i pierwszej połowie XV wieku, Inowrocław 2005.

Koczerska M., „Composicio clenodiorum” - fikcyjna konfederacja, w: Parlament, prawo, ludzie. Studia ofiarowane profesorowi Juliuszowi Bardachowi w sześćdziesięciolecie pracy twórczej, Warszawa 1996.

Koczerska M., Rzeczywistość i fikcja w formularzach polskich XV w., w: Literatura i kultura polskiego średniowiecza. Człowiek wobec świata znaków i symboli, Warszawa 1995.

Kolankowski L., Dzieje Wielkiego Księstwa Litewskiego za Jagiellonów, t. I, Warszawa 1930.

Kurtyka J., Z dziejów walki szlachty ruskiej o równouprawnienie: represje lat 1426-1427 i sejmiki roku 1439, Roczniki Historyczne 66, 2000.

Kurtyka J., Tęczyńscy. Studium z dziejów polskiej elity możnowładczej w średniowieczu, Kraków 1997. 
Laberschek J., Początki i rozwój miasta Szczekociny do końca XV w. Uwagi do genealogii Szczekockich herbu Odrowąż, w: Patientia et tempus. Księga jubileuszowa dedykowana doktorowi Marianowi Korneckiemu, Kraków 1999.

Lewicki A., Powstanie Świdrygiełły. Ustęp z dziejów unii Litwy z Koroną, Kraków 1892.

Nabiałek K., Starostwo olsztyńskie od XIV do połowy XVII wieku, Kraków 2012.

Nowak Z.H., Puchała Dobiesław, w: Polski słownik biograficzny, t. XXIX (1986).

Ożóg K., Piotr Woda ze Szczekocin, w: Polski słownik biograficzny, t. XXVI (1981).

Piekosiński F., Jana Zamoyskiego notaty heraldyczno-sfragistyczne, w: tegoż, Studia, rozprawy i materiały z dziedziny historii polskiej i prawa polskiego, t. I, Kraków 1907.

Polechow S., Szybkowski S., Królewski dokument rozejmu ze Świdrygiełłą z 20 VIII 1431 roku, Roczniki Historyczne 83, 2017.

Prochaska A., Przebaczenie królewskie ziemianom oleskim w 1431 r., Kwartalnik Historyczny 9, 1895.

Radzimiński A., Prałaci i kanonicy kapituły katedralnej płockiej w XIV i I poł. XV w. Studium prozopograficzne, t. 1, Toruń 1991.

Roman S., Konflikt prawno-polityczny 1425-1430 roku a przywilej brzeski, Czasopismo Prawno-Historyczne 14, 1962, z. 1.

Słownik historyczno-geograficzny ziemi chełmińskiej w średniowieczu, opr. K. Porębska, M. Grzegorz, Wrocław 1971.

Sochacka A., Jan z Czyżowa namiestnik Władysława Warneńczyka. Kariera rodziny Półkozów w średniowieczu, wyd. 2, Oświęcim 2016.

Sperka J., Osobiste akty hołdownicze panów polskich z okresu panowania Władysława Jagiełły, w: Społeczeństwo Polski średniowiecznej, t. IX, Warszawa 2001.

Sperka J., Szafrańcowie herbu Stary Koń. Z dziejów kariery i awansu w późnośredniowiecznej Polsce, Katowice 2001.

Spieralski Z., Z dziejów Archiwum Koronnego Krakowskiego. Kopiariusz Jana Łaskiego (około 1505), cz. I, Studia Źródłoznawcze 24, 1979.

Szybkowski S., Kościeleccy ze Skępego herbu Ogon i ich protoplaści. Studium z dziejów późnośredniowiecznej rodziny możnowładczej, Gdańsk 2018.

Szybkowski S., Nowe źródła do dziejów polsko-krzyżackich rokowań w Brześciu Kujawskim w grudniu 1435 r., Ziemia Kujawska 16, 2003.

Szybkowski S., Szlacheckie elity urzędnicze we wspólnocie terytorialnej w późnym średniowieczu (na przykładzie środkowopolskim), w: Człowiek w średniowieczu. Między biologią a historią, Łódź 2009.

Thumser M., Zehn Thesen zur Edition deutschsprachiger Geschichtsquellen (14.-16. Jahrhundert), w: Editionswissenschaftliche Kolloquien 2005/2007. Methodik - Amtsbücher - digitale Edition - Projekte, Torun 2008.

Trawka R., Szczekocki Dobiesław, w: Polski słownik biograficzny, t. XLVII (2010-2011).

Trawka R., Szczekocki Jan, w: Polski słownik biograficzny, t. XLVII (2010-2011).

Uruszczak W., Najstarszy sejm walny koronny ,dwuizbowy” w Piotrkowie w 1468 roku, w: Narodziny Rzeczypospolitej. Studia z dziejów średniowiecza i czasów wczesnonowożytnych, t. II, Kraków 2012.

Uruszczak W., Poselstwo sejmowe w dawnej Polsce. Posłaniec, mandatariusz, poseł narodu, Czasopismo Prawno-Historyczne 61, 2009, z. 1.

Uruszczak W., Poselstwo sejmowe w dawnej Polsce, w: Drogi i bezdroża nauk historyczno-prawnych, Bielsko-Biała 2010.

Urzędnicy kujawscy i dobrzyńscy XII-XV wieku. Spisy, opr. J. Bieniak, S. Szybkowski, Kórnik 2014.

Urzędnicy łęczyccy, sieradzcy i wieluńscy XIII-XV wieku. Spisy, opr. J. Bieniak, A. Szymczakowa, Wrocław 1985.

Urzędnicy wielkopolscy XII-XV wieku. Spisy, red. A. Gąsiorowski, Wrocław 1985.

Wilk-Woś Z., Władysław z Oporowa (ok. 1395-1453), podkanclerzy królewski, biskup włocławski i arcybiskup gnieźnieński, Studia Claramontana 21, 2003. 
Wróbel D., Elity polityczne Królestwa Polskiego wobec problemu krzyżackiego w czasach Władysława Jagiełły, Lublin 2016.

Zawitkowska W., Walka polityczno-prawna o następstwo tronu po Władysławie Jagielle w latach 1424-1434, Rzeszów 2015.

Żebrowski T., Pawłowski Stanisław, w: Polski słownik biograficzny, t. XXV (1980).

Бучинський Б., Кілька причинків до часів вел. князя Свитригайла (1430-1433), Записки Наукового товариства ім. Шевченка 76, 1907.

Грушевський М.С., Історія України-Руси, т. IV, Львів 1907 (reprint: Київ 1993).

Полехов С.В., Наследники Витовта. Династическая война в Великом княжестве Литовском в 30-е годы XV века, Москва 2015.

\section{A new source for the history of Polish estate representation development in late Middle Ages. The report of the Teutonic Knights informer Nikolaus Steinchen from early December 1432}

\section{Summary}

The paper presents the edition and critical analysis of an undated report from an informer of the Teutonic Knights. Its author was successfully identified as Nikolaus Steinchen, belonging to the close surrounding of Stanisław Pawłowski, the bishop of Płock. The report was probably written shortly after 1 December 1432 . The details contained in the spy's relation must be accepted as highly credible. The report is also a new source for the history of Polish estate representation development. The spy informs that the voivod of Brześć Kujawski, at the particular meeting in Bobrowniki, handed to the nobility of Dobrzyń Land the royal summons to the general meeting in Cracow on 25 December 1432. King Ladislaus Jagiello ordered that two "seniors" from every heraldic clan in every land of the Kingdom of Poland should come. A similar "clan" form for the representation of lower nobility (gentry) was used for issuing documents to the nobility of Brześć Kujawski Voivodship and Dobrzyń Land concerning the succession to the Polish throne after the death of Landislaus Jagiello (1433 and 1434). Such form was proposed by the king and his chancellery, and was an element of searching for the best way to appoint the estate representation of lower nobility. However, it cannot be found in tributary documents of Ruthenian nobility (1427), nor in the document issued to the nobility of Poznań Voivodship in 1432, nor can it be found later, after the death of Ladislaus Jagiello (1434). 